\title{
PENINGKATAN HASIL BELAJAR SISWA MELALUI MODEL PEMBELAJARAN KOOPERATIF SNOWBALL THROWING PADA SISWA KELAS IV SD NEGERI 165721 KOTA TEBING TINGGI
}

\author{
Aridawaty \\ Surel: s.pdaridawaty@yahoo.com
}

\begin{abstract}
ABSTRAK
Penelitian ini bertujuan meningkatkan hasil belajar siswa kelas IV SD Negeri 165721 Tebing Tinggi pada pelajaran pendidikan kewarganegaraan dengan model pembelajaran kooperatif snowball throwing. Subjek penelitian ini yaitu siswa kelas IV berjumlah 30 orang. Peningkatan hasil belajar diperoleh yaitu pada siklus I mencapai 67 dan siklus II mencapai 83. Pada siklus II, kesungguhan siswa mengikuti pelajaran PKn lebih meningkat. Ketepatan dalam membuat pertanyaan siswa memperoleh nilai rata-rata 85 dan dalam menjawab pertanyaan siswa memperoleh 75 . Rata-rata kognitif siswa pada siklus II memperoleh 83. Hasil penelitian menggunakan model pembelajaran kooperatif snowball throwing pada pelajaran PKn ternyata cukup efektif meningkatkan prestasi belajar siswa.
\end{abstract}

Kata Kunci : Hasil Belajar, Model Pembelajaran, Snowball Throwing

\section{PENDAHULUAN}

Guru memiliki peranan yang sangat penting dalam menentukan kuantitas dan kualitas pengajaran yang dilaksanakan. Oleh sebab itu, guru harus memikirkan dan membuat perencanaan secara seksama dalam meningkatkan kesempatan belajar bagi siswanya dan memperbaiki kualitas mengajarnya.

Hal ini menuntut perubahanperubahan dalam mengorganisasikan kelas, penggunaan metode mengajar, strategi belajar mengajar, maupun sikap dan karakteristik guru dalam mengelola proses belajar mengajar. Guru berperan sebagai pengelola proses belajar-mengajar, bertindak sebagai fasilitor yang berusaha menciptakan kondisi belajar mengajar yang efektif, sehingga memungkinkan proses belajar mengajar, mengembangkan bahan pelajaran dengan baik, dan meningkatkan kemampuan siswa untuk menyimak pelajaran Pkn, mengenal sistem pemerintahan dan menguasai tujuan-tujuan pendidikan yang harus mereka capai. Untuk memenuhi hal tersebut di atas, guru dituntut mampu mengelola proses belajar mengajar yang memberikan rangsangan kepada siswa, sehingga ia mau belajar karena siswalah subyek utama dalam belajar.

Dalam hal ini yang akan di identifikasi masalah adalah:

1. Guru monoton sehingga kondisi dikelas membosankan.

2. Guru kurang kreatif.

3. Guru hanya menggunakan alat peraga yang sudah jadi. 
4. Siswa kurang memahami pelajaran yang diberikan.

Penelitian ini dibatasi pada pelaksanaan pembelajaran PKn mengenai sistem pemerintahan tingkat pusat. Pengamatan lebih difokuskan pada keterlaksanaan proses pembelajaran dengan model pembelajaran Snowball throwing yang diharapkan dapat meningkatkan hasil belajar siswa.

Dari permasalahan yang telah dikemukakan di atas, maka rumusan permasalahan yang diajukan oleh peneliti adalah:

1. Bagaimana meningkatan hasil belajar siswa pada pelajaran PKn melalui model pembelajaran snowball throwing di SD Negeri 165721 ?

2. Apakah siswa mampu memahami dan menguasai pelajaran dengan menggunakan model pembelajaran tersebut?

Adapun tujuan dari penelitian ini adalah:

Tujuan Umum

Agar dapat mengkongkritkan pembelajaran dan dapat melibatkan siswa dalam pembelajaran PKn sehingga pembelajaran lebih bermakna bagi siswa.

\section{Tujuan Khusus}

Untuk mengetahui apakah dengan menggunakan media dalam pembelajaran PKn dapat meningkatkan hasil belajar siswa.
Manfaat dari penelitian ini yaitu:

\section{Bagi Siswa}

a. Membantu siswa lebih memahami dan mengenal sistem pemerintahan pusat.

b. Meningkatkan hasil belajar PKn siswa.

c. Menciptakan pembelajaran PKn yang kreatif dan menyenangkan.

Manfaat Bagi Guru

a. Meningkatkan kualitas guru dalam melaksanakan tugas mengajar.

b. Merangsang guru-guru yang lain untuk melakukan pembelajaran yang kreatif dan menyenangkan bagi siswa.

\section{Manfaat Bagi Sekolah}

a. Meningkatkan hasil belajar para siswa SD Negeri 165721 Kota Tebing Tinggi khususnya pada mata pelajaran PKn.

b. Agar SD Negeri 165721 Kota Tebing Tinggi mampu bersaing dengan SD yang lain dalam hal inovasi di dalam pembelajaran.

Menurut W.J.S Purwadarminto (1987:767) menyatakan bahwa hasil belajar adalah hasil yang dicapai sebaik-baiknya menurut kemampuan anak pada waktu tertentu terhadap hal-hal yang dikerjakan atau dilakukan. Hasil belajar menurut Winkel (1996:226) mengemukakan bahwa hasil belajar merupakan bukti keberhasilan yang telah dicapai oleh seseorang. Sedangkan menurut Arif Gunarso (1993:77) mengemukakan 
bahwa hasil adalah usaha maksimal yang dicapai oleh seseorang setelah melaksanakan usaha-usaha belajar.

Berdasarkan

beberapa

pengertian di atas, dapat peneliti simpulkan bahwa yang dimaksud dengan hasil belajar adalah hasil terbaik yang dicapai siswa setelah melaksanakan usaha belajar secara maksimal. Salah satu pemikiran konstruktivisme yang banyak digunakan sebagai rujukan untuk memahami perkembangan kognitif individu yaitu teori tentang tahapan perkembangan individu.

Pendidikan Kewarganegaraan merupakan salah satu pembelajaran yang tertumpu pada bidang sosial yang mencakup nilai-nilai adab kesopanan dan sosial kemasyarakatan. Dalam pembelajaran PKN siswa diajarkan bagaimana cara melakukan sosialisasi dan beradaptasi pada lingkungan di sekitar tempat tinggalnya. PKn timbul karena pikiran-pikiran manusia yang berhubungan dengan ide dan penalaran, karena ide-ide yang dihasilkan oleh pikiran-pikiran manusia itu merupakan sistem-sistem yang bersifat deduktif sehingga berlaku umum dalam menyelesaikan masalah.

Snowball secara etimologi berarti bola salju, sedangkan throwing artinya melempar. Snowball Throwing secara keseluruhan dapat diartikan melempar bola salju. Menurut Saminanto, model pembelajaran snowball throwing disebut juga model pembelajaran gelundungan bola salju. Model pembelajaran ini melatih siswa untuk lebih tanggap menerima pesan dari siswa lain dalam bentuk bola salju yang terbuat dari kertas, dan menyampaikan pesan tersebut kepada temannya dalam satu kelompok. Sedangkan menurut Kisworo model pembelajaran snowball throwing adalah suatu model pembelajaran yang diawali dengan pembentukan kelompok yang diwakili ketua kelompok untuk mendapat tugas dari guru kemudian masing-masing siswa membuat pertanyaan yang dibentuk seperti bola (kertas pertanyaan) lalu dilempar ke siswa lain yang masingmasing siswa menjawab pertanyaan dari bola yang diperoleh. Menurut Suprijono dan Saminanto, langkahlangkah pembelajaran model pembelajaran snowball throwing adalah:

1. Guru menyampaikan materi yang akan disajikan dan KD yang ingin dicapai.

2. Guru membentuk siswa berkelompok, lalu memanggil masing-masing ketua kelompok untuk memberikan penjelasan tentang materi.

3. Masing-masing ketua kelompok kembali ke kelompoknya masing-masing, kemudian menjelaskan materi yang disampaikan oleh guru kepada temannya.

4. Kemudian masing-masing siswa diberikan satu lembar kertas kerja, untuk menuliskan satu pertanyaan apa saja yang 
menyangkut materi yang sudah dijelaskan oleh ketua kelompok.

5. Kemudian kertas yang berisi pertanyaan tersebut dibuat seperti bola dan dilempar dari satu siswa ke siswa yang lain selama \pm 5 menit.

6. Setelah siswa dapat satu bola/satu pertanyaan diberikan kesempatan kepada siswa untuk menjawab pertanyaan yang tertulis dalam kertas berbentuk bola tersebut secara bergantian.

7. Evaluasi.

8. Penutup.

Untuk meningkatkan hasil belajar PKn, dalam pembelajarannya harus menarik sehingga siswa termotivasi untuk belajar. Diperlukan model pembelajaran interaktif dimana guru lebih banyak memberikan peran kepada siswa sebagai subjek belajar. Guru merancang proses belajar mengajar yang melibatkan siswa secara integratif dan komprehensif pada aspek kognitif, afektif dan psikomotorik sehingga tercapai hasil belajar. Agar hasil belajar PKn meningkat diperlukan situasi, cara dan strategi pembelajaran yang tepat untuk melibatkan siswa secara aktif, baik pikiran, pendengaran, penglihatan, dan perbuatan dalam proses belajar mengajar.

Hipotesis tindakan dalam penelitian tindakan kelas ini adalah apabila penerapan model belajar snowball throwing dengan variasi media pembelajaran dapat berjalan efektif, maka hasil belajar siswa akan meningkat.
ESJ VOLUME 5, NO. 1, JUNI 2016

\section{METODE PENELITIAN}

Jenis penelitian yang dilaksanakan adalah penelitian tindakan kelas. Tindakan yang diberikan adalah penerapan model pembelajaran kooperatif tipe snowball throwing.

Penelitian Tindakan kelas ini berlokasi di SD Negeri 165721 berada di Jalan Danau Maninjau Kelurahan Padang Merbo Kecamatan Padang Hulu.

Perkiraan waktu yang dibutuhkan dalam melakukan penelitian selama tiga bulan, yang mana penelitian tersebut dimulai di bulan Januari sampai dengan bulan Maret tahun 2015.

Subjek dalam penelitian ini adalah siswa kelas IV SD Negeri 165721 Kota Tebing Tinggi Kecamatan Padang Hulu Kelurahan Padang Merbau. Jumlah Siswa 30 orang, 11 siswa laki-laki dan 19 orang perempuan.

Rancangan penelitian adalah Penelitian Tindakan Kelas (PTK). Penelitian terdiri atas 2 siklus yang disebut dengan Siklus 1 dan Siklus 2.

\section{Siklus 1}

Rencana tindakan

Pada tahap ini peneliti melakukana beberapa aktivitas yaitu

1) Membuat RPP tentang materi "Mengenal sistem pemerintahan tingkat pusat" 
Aridawaty: Peningkatan Hasil Belajar Siswa ...

tersebut diatas.

3) Menyiapkan siswa menjadi enam kelompok belajar dan setiap kelompok ter ${ }^{*}$

4) Peneliti me p-ISSN 2407-4934 Peneliti me p-ISSN 2407-4934 untuk menivuar nuspanataı dengan Kepala Sekolah (manager sekolah), agar dapat melaksanakan penelitian.

5) Menyiapkan lembar pengamatan atau observasi.

6) Menyusun lembar observasi mengenai partisipasi siswa dalam PBM di kelas IV SD Negeri 165721 Kota Tebing Tinggi.

\section{Pelaksanaan Tindakan.}

Penerapan model pembelajaran Snowball throwing dilakukan dengan menugaskan kepada masing-masing kelompok untuk mendiskusikan materi ajar "mengenal sistem pemerintahan tingkat pusat."

Suasana pembelajaran masing-masing kelompok di kelas dikondisikan agar tidak terlalu formal, maksudnya siswa bebas mengevaluasi hasil tindakan yang telah dilakukan.

\section{Siklus ke 2}

Pada siklus kedua ini juga diadakan perencanaan seperti pada siklus satu yaitu tahap perencanaan, tindakan, observasi dan refleksi dalam suatu konsep yang saling terkait. Hanya saja pada siklus kedua mengemukakan pendapatnya tentang materi ajar sesuai dengan kompetensi dasar yang ingin dicapai.

\section{Observasi}

Guru/Peneliti sekaligus sebagai observator dibantu oleh dua orang Guru lainnya melakukan observasi/pengamatan terhadap semua kejadian pada PBM untuk dijadikan acuan dalam membuat catatan (Vignette) dan pengisian lembar observasi yang telah dibuat selama proses pembelajaran Pendidikan Kewarganegaraan di kelas maupun di lingkungan sekitar sekolah .

\section{Refleksi}

Data yang diperoleh pada lembar observasi, dianalisis. Kemudian dilakukan refleksi. Pelaksanaan refleksi merupakan hasil observasi/pengamatan peneliti pada saat melakukan observasi di kelas maupun di lingkungan sekitar sekolah yang bertujuan untuk

ini ada perubahan yang menuju kearah yang lebih baik jika dibandingkan dengan siklus satu.

\section{HASIL DAN PEMBAHASAN \\ Data Aktivitas Belajar siswa}

Data mengenai aktivitas siswa dalam proses belajar mengajar dapat diuraikan berdasarkan siklus berikut

ini: 


\section{Tabel Skor Aktivitas Siswa pada Siklus 1}

p-ISSN 2407-4934

e-ISSN 2355-1747

\begin{tabular}{l|l|c}
\hline diamati & \multicolumn{2}{|c}{ Kelompok } \\
\cline { 2 - 3 } & 1 & 2
\end{tabular}

\begin{tabular}{|l|c|c|c|c|c|}
\hline $\begin{array}{l}\text { 1. Siswa mendengarkan dan } \\
\text { memperhatikan penjelasan Guru }\end{array}$ & 1 & 3 & 2 & 3 & 3 \\
\hline $\begin{array}{l}\text { 2. Siswa selalu berada dalam } \\
\text { kelompoknya }\end{array}$ & 2 & 3 & 2 & 3 & 3 \\
\hline 3. Siswa aktif dalam kelompoknya & 3 & 2 & 3 & 2 & 3 \\
\hline $\begin{array}{l}\text { 4. Siswa yang merasa kaku berada } \\
\text { dalam kelompoknya }\end{array}$ & 3 & 3 & 3 & 2 & 3 \\
\hline $\begin{array}{l}\text { 5. Siswa berdiskusi dengan teman } \\
\text { kelompoknya dalam menyelesaikan } \\
\text { masalah dalam LKS }\end{array}$ & 2 & 3 & 2 & 2 & 2 \\
\hline $\begin{array}{l}\text { 6. Siswa mengalami kesulitan dalam } \\
\text { menyelesaikan masalah dalam LKS }\end{array}$ & 2 & 3 & 2 & 1 & 2 \\
\hline $\begin{array}{l}\text { 7. Siswa mengajukan pertanyaan } \\
\text { kepada Guru saat mengalami } \\
\text { kesulitan dalam menyelesaikan } \\
\text { masalah dalam LKS }\end{array}$ & 2 & 2 & 3 & 2 & 3 \\
\hline $\begin{array}{l}\text { 8. Ada rasa takut pada siswa ketika } \\
\text { nomor anggotanya terpanggil }\end{array}$ & 2 & 3 & 3 & 2 & 3 \\
\hline $\begin{array}{l}\text { 9. Siswa mampu menjawab atau } \\
\text { mempresentasikan hasil kerja } \\
\text { kelompoknya di depan kelas }\end{array}$ & 1 & 2 & 2 & 2 & 2 \\
\hline $\begin{array}{l}\text { 10. Siswa membuat rangkuman tentang } \\
\text { materi yang dipelajari }\end{array}$ & 1 & 2 & 2 & 2 & 2 \\
\hline Rata-Rata Aktivitas Kelompok & $\mathbf{1 , 9 0}$ & $\mathbf{2 , 6 0}$ & $\mathbf{2 , 4 0}$ & $\mathbf{2 , 1 0}$ & $\mathbf{2 , 6 0}$ \\
\hline Kategori Kurang & Cukup & $\mathbf{C u k u p}$ & $\mathbf{C u k u p}$ & $\mathbf{C u k u p}$ \\
\hline
\end{tabular}

Berdasarkan tabel di atas menunjukkan rata-rata aktivitas siswa pada pertemuan 1 siklus 1 tergolong rendah, dimana kelompok 1 mempunyai rata-rata 1,90 ; kelompok 2 sebesar 2,60; kelompok 3 sebesar 2,40; kelompok 4 sebesar 2,10; dan kelompok 5 sebesar 2,60; Dari data tersebut, dapat dikategorikan menjadi
2 kategori yakni kategori kurang seperti kelompok 1 dan kategori cukup seperti kelompok 2, kelompok 3, dan kelompok 5. Untuk mendapatkan gambaran rata-rata aktivitas belajar siswa pada siklus 2 dapat dilihat pada tabel berikut ini:

Tabel Skor Aktivitas Siswa pada Siklus 2

\begin{tabular}{|l|c|c|c|c|c|}
\hline & \multicolumn{5}{|c|}{ Kelompok } \\
\cline { 2 - 6 } Aspek yang dinilai dan diamati & \multicolumn{5}{|c|}{$\mathbf{3}$} \\
\cline { 2 - 6 } dan & $\mathbf{1}$ & $\mathbf{2}$ & $\mathbf{3}$ & $\mathbf{4}$ & $\mathbf{5}$ \\
\hline $\begin{array}{l}\text { 1. Siswa mendengarkan penjelasan } \\
\text { memperhatikan }\end{array}$ & 3 & 3 & 4 & 4 & 3 \\
\hline
\end{tabular}


Aridawaty: Peningkatan Hasil Belajar Siswa ...

\begin{tabular}{|c|c|c|c|c|c|}
\hline Guru & & & & & \\
\hline $\begin{array}{l}\text { 2. Siswa selalu berada dalam } \\
\text { kelompoknya }\end{array}$ & 4 & 3 & 3 & 4 & 2 \\
\hline 3. Siswa aktif dalam kelompoknya & 4 & 3 & 4 & 4 & 3 \\
\hline $\begin{array}{l}\text { 4. Siswa yang merasa kaku berada } \\
\text { dalam kelompoknya }\end{array}$ & 2 & 2 & 2 & 1 & 2 \\
\hline $\begin{array}{ll}\text { 5. } & \text { Siswa berdiskusi dengan teman } \\
\text { kelompoknya } & \text { dalam } \\
\text { menyelesaikan masalah dalam } & \\
\text { LKS } & \end{array}$ & 2 & 2 & 4 & 4 & 3 \\
\hline $\begin{array}{l}\text { 6. Siswa mengalami } \text { kesulitan } \\
\text { dalam menyelesaikan masalah } \\
\text { dalam LKS }\end{array}$ & 3 & 2 & 2 & 2 & 2 \\
\hline $\begin{array}{l}\text { 7. Siswa mengajukan pertanyaan } \\
\text { kepada Guru saat mengalami } \\
\text { kesulitan dalam menyelesaikan } \\
\text { masalah dalam LKS }\end{array}$ & 2 & 3 & 2 & 2 & 3 \\
\hline $\begin{array}{l}\text { 8. Ada rasa takut pada siswa } \\
\text { ketika nomor anggotanya } \\
\text { terpanggil }\end{array}$ & 3 & 2 & 2 & 1 & 1 \\
\hline $\begin{array}{l}\text { 9. Siswa mampu menjawab atau } \\
\text { mempresentasekan hasil kerja } \\
\text { kelompoknya di depan kelas }\end{array}$ & 4 & 4 & 4 & 3 & 3 \\
\hline $\begin{array}{l}\text { 10. Siswa membuat rangkuman } \\
\text { tentang materi yang dipelajari }\end{array}$ & 3 & 3 & 4 & 2 & 2 \\
\hline Rata-Rata Aktivitas Kelompok & 3,0 & 2,7 & 3,1 & 2,7 & 2,4 \\
\hline Kategori & Baik & Cukup & Baik & Cukup & Cukup \\
\hline
\end{tabular}

Tabel Distribusi Rata-Rata Aktivitas Siswa Pada Setiap Siklus

\begin{tabular}{|c|c|c|c|c|}
\hline \multirow[b]{2}{*}{ Aspek Yang Dinilai } & \multicolumn{4}{|c|}{ Siklus } \\
\hline & I & $\begin{array}{l}\text { Katego } \\
\text { ri }\end{array}$ & II & $\begin{array}{c}\text { Kategor } \\
\text { i }\end{array}$ \\
\hline $\begin{array}{l}\text { 1. siswa mendengarkan dan memperhatikan } \\
\text { penjelasan Guru }\end{array}$ & 3,86 & Baik & 3,86 & Baik \\
\hline 2. siswa selalu berada dalam kelompoknya & 3,71 & Baik & 3,57 & Baik \\
\hline 3. $\quad$ siswa aktif dalam kelompoknya & 3,57 & Baik & 4,00 & $\begin{array}{c}\text { Sangat } \\
\text { baik }\end{array}$ \\
\hline $\begin{array}{l}\text { 4. siswa yang merasa kaku berada dalam } \\
\text { kelompoknya }\end{array}$ & 2,43 & Cukup & 2,43 & Cukup \\
\hline $\begin{array}{llr}5 . & \text { siswa berdiskusi dengan teman } \\
& \text { kelompoknya dalam } \\
\text { masalah dalam LKS } & \text { menyelesaikan } \\
\end{array}$ & 3,43 & Baik & 4,00 & $\begin{array}{l}\text { Sangat } \\
\text { baik }\end{array}$ \\
\hline $\begin{array}{llcc}6 . & \text { siswa mengalami kesulitan } & \text { dalam } \\
& \text { menyelesaikan masalah dalam LKS } & \\
\end{array}$ & 2,71 & Cukup & 2,71 & Cukup \\
\hline $\begin{array}{l}\text { 7. siswa mengajukan pertanyaan kepada Guru } \\
\text { saat mengalami kesulitan dalam }\end{array}$ & 2,43 & Cukup & 3,00 & Baik \\
\hline
\end{tabular}


ESJ VOLUME 5, NO. 1, JUNI 2016

\begin{tabular}{|c|c|c|c|c|}
\hline menyelesaikan masalah dalam LKS & & & & \\
\hline $\begin{array}{l}\text { 8. ada rasa takut pada siswa ketika nomor } \\
\text { anggotanya terpanggil }\end{array}$ & 2,00 & Kurang & 2,29 & Cukup \\
\hline $\begin{array}{llrr}\text { 9. } & \text { siswa mampu } & \text { menjawab } & \text { atau } \\
\text { mempresentasekan } & \text { hasil } & \text { kerja } \\
\text { kelompoknya di depan kelas } & \end{array}$ & 3,71 & Baik & 2,71 & Cukup \\
\hline $\begin{array}{l}\text { 10. siswa membuat rangkuman tentang materi } \\
\text { yang dipelajari }\end{array}$ & 1,29 & Kurang & 3,00 & Baik \\
\hline Rata-Rata Aktivitas Siswa & 2,91 & & 3,16 & \\
\hline Kategori & Cukup & & Baik & \\
\hline
\end{tabular}

Data Aktivitas Guru selama KBM Berlangsung

Untuk

gambaran aktivitas Guru dalam

mengelola pembelajaran dengan menggunakan model pembelajaran snowball throwing pada pelajaran PKn materi pengenalan sistem pemerintahan pusat dapat dilihat pada tabel

berikut:

Tabel Skor Aktivitas Guru pada Siklus 1

\begin{tabular}{|c|c|}
\hline Aspek Yang Diamati Selama KBM & Penilaian \\
\hline $\begin{array}{l}\text { 1. Memberitahu siswa tentang pendekatan } \\
\text { pembelajaran yang digunakan }\end{array}$ & 3 \\
\hline 2. Memotivasi siswa untuk belajar & 1 \\
\hline $\begin{array}{l}\text { 3. Menyampaikan tujuan/indikator yang harus dicapai } \\
\text { dalam proses pembelajaran }\end{array}$ & 1 \\
\hline $\begin{array}{l}\text { 4. Memberi apersepsi kepada siswa sebelum memasuki } \\
\text { materi pembelajaran }\end{array}$ & 2 \\
\hline 5. Mengorganisasi siswa dalam kelompok & 4 \\
\hline 6. Menyiapkan LKS untuk siswa & 4 \\
\hline 7. Menjelaskan cara kerja dalam LKS kepada siswa & 3 \\
\hline $\begin{array}{l}\text { 8. Meminta siswa secara berkelompok menyelesaikan } \\
\text { masalah dalam LKS }\end{array}$ & 4 \\
\hline $\begin{array}{l}\text { 9. Membimbing siswa dalam setiap } \\
\text { menyelesaikan masalah dalam LKS }\end{array}$ & 4 \\
\hline 10. Mengamati siswa bekerja dalam kelompoknya & 3 \\
\hline $\begin{array}{l}\text { 11. Memanggil nomor anggota siswa dalam kelompok } \\
\text { untuk menjawab atau mempresentasekan hasil kerja } \\
\text { kelompoknya }\end{array}$ & 4 \\
\hline $\begin{array}{l}\text { 12. Memberikan penghargaan kepadakelompok yang } \\
\text { memperoleh hasil terbaik }\end{array}$ & 1 \\
\hline 13. Mengarahkan siswa kejawaban yang benar & 3 \\
\hline 14. Menyuruh siswa membuat rangkuman & 1 \\
\hline Rata-Rata Aktivitas Guru & 2,71 \\
\hline Kategori & Cukup \\
\hline
\end{tabular}


Tabel Skor Aktivitas Guru pada Siklus 2

\begin{tabular}{|c|c|}
\hline Aspek Yang Diamati Selama KBM & p-ISSN 2407-4934 \\
\hline $\begin{array}{l}\text { Memberitahu siswa tentang pendekatan } \\
\text { pembelajaran yang digunakan }\end{array}$ & $\begin{array}{l}\text { e-ISSN 2355-1747 } \\
3\end{array}$ \\
\hline Memotivasi siswa untuk belajar & 3 \\
\hline $\begin{array}{l}\text { Menyampaikan tujuan/indikator yang harus dicapai } \\
\text { dalam proses pembelajaran }\end{array}$ & 4 \\
\hline $\begin{array}{l}\text { Memberi apersepsi kepada siswa sebelum memasuki } \\
\text { materi pembelajaran }\end{array}$ & 2 \\
\hline Mengorganisasi siswa dalam kelompok & 4 \\
\hline Menyiapkan LKS untuk siswa & 4 \\
\hline Menjelaskan cara kerja dalam LKS kepada siswa & 4 \\
\hline $\begin{array}{l}\text { Meminta siswa secara berkelompok menyelesaikan } \\
\text { masalah dalam LKS }\end{array}$ & 4 \\
\hline $\begin{array}{l}\text { Membimbing siswa dalam setiap } \\
\text { menyelesaikan masalah dalam LKS }\end{array}$ & 4 \\
\hline Mengamati siswa bekerja dalam kelompoknya & 3 \\
\hline $\begin{array}{l}\text { Memanggil nomor anggota siswa dalam kelompok } \\
\text { untuk menjawab atau mempresentasekan hasil kerja } \\
\text { kelompoknya }\end{array}$ & 4 \\
\hline $\begin{array}{rcc}\text { Memberikan penghargaan } & \text { kepadakelompok yang } \\
\text { memperoleh hasil terbaik } & & \end{array}$ & 3 \\
\hline Mengarahkan siswa kejawaban yang benar & 3 \\
\hline Menyuruh siswa membuat rangkuman & 3 \\
\hline Rata-Rata Aktivitas Guru & 3,36 \\
\hline Kategori & Baik \\
\hline
\end{tabular}

\section{a. Siklus 1}

Berdasarkan hasil analisis deskriptif terhadap hasil belajar siswa pada siklus 1 dengan skor minimum sebesar 40, nilai maksimum sebesar 95, rata-rata hasil belajar siswa sebesar 73,21. Pada kondisi ini ternyata terdapat 8 orang siswa yang belum tuntas karena memperoleh nilai di bawah KKM yang telah ditentukan oleh sekolah yaitu $\geq 60$, dan 20 orang siswa atau $75,00 \%$ -belajaran ini tampak bahwa siswa dalam kelompoknya masih cenderung pasif dalam menerima pelajaran dari Guru, artinya bahwa siswa masih cenderung mendengarkan penjelasan Guru, kurang membaca buku teks atau LKS, dan kurang berdiskusi baik sesama siswa maupun kepada Guru. Selain itu pula, kurangnya pemahaman siswa dalam menyelesaikan soal-soal Ekonomi sehingga berdampak pada 
kemampuan siswa menyelesaikan soal-soal sehubungan dengan materi ajar Pengenalan sistem pemerintahan pusat. Berdasarkan beberapa aspek tersebut di atas diduga berpengaruh pada hasil belajar Ekonomi siswa, khususnya bagi siswa yang belum mencapai KKM.

Setelah melakukan analisis dan refleksi pada siklus 1, para observer dan peneliti mencoba mengadakan beberapa perbaikan dalam proses belajar-mengajar diantaranya penekanan dalam pengorganisasian siswa belajar dalam kelompok yang ditempuh dengan mengadakan diskusi baik dengan guru maupun dengan sesama siswa.

\section{b. Siklus 2}

Berdasarkan hasil analisis deskriptif terhadap hasil belajar siswa pada siklus 2, terlihat bahwa hasil belajar siswa pada materi ajar Pengenalan sistem pemerintahan pusat dengan skor minimum sebesar 50, skor maksimum sebesar 100, dan rata-rata hasil belajar siswa sebesar 79,28. Pada kondisi ini terdapat 5 orang siswa yang belum tuntas karena memperoleh nilai di bawah KKM yang telah ditentukan oleh sekolah yaitu $\geq 60$, dan 37 orang siswa atau $88,09 \%$ siswa yang sudah tuntas karena memperoleh nilai $\geq 60$.

Pada siklus 2 hasil belajar siswa sudah menunjukkan peningkatan jika dibandingkan dengan siklus 1. Peningkatan hasil belajar siswa pada siklus 2 menunjukkan adanya peningkatan penguasaan siswa terhadap materi pel ESJ VOLUME 5, NO. 1, JUNI 2016

$\mathrm{ad} c$

mencapai ketutasan belajar disebabkan karena masih adanya siswa yang belum memahami penyelesaian soal-soal Ekonomi dengan baik.

Berdasarkan hasil analisis deskriptif terhadap peningkatan hasil belajar siswa dari siklus 1 sampai siklus 2, menunjukkan adanya ratarata peningkatan hasil belajar yang signifikan dari siklus 1 ke siklus 2 yang mengalami peningkatan.

Peningkatan hasil belajar siswa juga terlihat pada hasil tes awal, bahwa berdasarkan hasil analisis diperoleh rata-rata hasil tes awal siswa sebesar 60,83 dimana nilai maksimum siswa sebesar 80 dan nilai minimum siswa sebesar 25 dan jumlah siswa yang belum mencapai KKM yang ditentukan oleh sekolah yaitu $\geq 60$ atau nilainya $<60$ berjumlah 28 orang serta jumlah siswa yang telah mencapai KKM atau nilainya $\geq 60$ berjumlah 14 orang atau sebesar 33,33\%. Secara umum, ketuntasan skenario pelaksanaan pembelajaran yang dilakukan guru mencapai 89,29\%.

Hal ini menunjukkan besarnya perubahan pamahaman siswa terhadap materi ajar Pengenalan sistem pemerintahan pusat setelah menerapkan model pembelajaran snowball throwing meningkat ke arah yang lebih baik. Dari hasil pengamatan terhadap hasil tes awal dan tes siklus seluruh siswa kelas IV SD Negeri 165721 Tebing Tinggi terlihat bahwa rata-rata siswa lebih 
Aridawaty: Peningkatan Hasil Belajar Siswa ...

pertanyaan yang berkaitan dengan materi ajar Pengenalan sistem pemerintahan pusat dengan benar.

Berdasarkan tabel di atas dapat terlihat adanya peningkatan yang signifikan dari tes awal, tes siklus 1 dan 2 siswa. Peningkatan tersebut dipengaruhi oleh adanya pemahaman siswa akan materi pembelajaran serta adanya motivasi siswa yang tinggi dalam mengikuti pembelajaran sampai pertemuan terakhir.

Berdasarkan hasil penelitian terhadap siswa kelas IV SD Negeri 165721 Kota Tebing Tinggi terjadi peningkatan hasil belajar dari siklus 1 ke siklus 2. Hal ini disebabkan karena:

1. Interaksi Guru

a. Guru mengorganisasikan waktu pembelajaran dengan baik.

b. Guru memberi motivasi dan apersepsi kepada siswa.

c. Guru mengikuti langkahlangkah pembelajaran yang terdapat dalam rencana pelaksanaan pembelajaran.

d. Guru mengarahkan dan memotivasi siswa untuk bertanya dan menyampaikan masukan.

e. Guru memberikan kesempatan kepada siswa untuk menjelaskan kembali pengetahuan yang telah diperolehnya.

f. Guru memberikan penghargaan berupa pujian kepada siswa ketika presentasi

didepan kelas dan inilah yang membuat siswa dalam kelompok model pembelajaran snowball throwing lebih termotivasi untuk jadi yang terbaik.

2. Interaksi Siswa

a. Siswa mampu beradaptasi dengan model pembelajaran yang diterapkan.

b. Siswa memperhatikan penyampaian Guru dan bersungguh-sungguh dalam belajar. Hal ini terlihat ketika Guru melakukan tanya jawab terjadi umpan balik dari siswa, meski ada saja siswa yang belum aktif.

c. Siswa aktif dalam memberi respon dalam kegiatan apersepsi.

d. Siswa cukup baik dalam menyimpulkan bahan ajar atau titik tekan materi yang telah diajarkan.

e. Siswa di setiap kelompok cukup baik dalam mengulangi atau menjelaskan kembali pengetahuan yang telah diperolehnya.

3. Interaksi Siswa dan Guru

a) Guru terampil dalam memandu diskusi siswa. Sehingga aktivitas ini dapat membantu meningkatkan hasil belajar siswa tentang materi yang diajarkan.

b) Siswa antusias untuk mengemukakan kesulitannya dalam menyusun dan 
menyelesaikan soal dan meminta bantuan atau bimbingan Guru.

Berdasarkan hasil analisis data deskriptif terhadap rata-rata aktivitas siswa dan hasil belajar siswa pada siklus 2 terlihat bahwa aktivitas siswa dalam kegiatan belajar mengajar cukup tinggi atau menunjukkan peningkatan yang signifikan dari siklus 1 sampai siklus 2, serta tingginya hasil belajar siswa yang telah mencapai standar ketuntasan belajar minimal secara individu dan klasikal seperti dipersyaratkan kurikulum. Berdasarkan hal itu penelitian tindakan kelas di kelas IV SD Negeri 165721 Tebing Tinggi dihentikan sampai siklus 2 .

\section{KESIMPULAN}

Berdasarkan hasil analisis dari beberapa siklus dan pembahasan, maka dapat disimpulkan bahwa:

1. Penerapan model pembelajaran snowball throwing dapat meningkatkan hasil belajar siswa kelas IV SD Negeri 165721 Kota Tebing Tinggi pada pelajaran Pendidikan Kewarganegaraan dalam materi pengenalan sistem pemerintah pusat. Fakta ini tergambar dari rata-rata aktivitas siklus 1 mencapai 2,91 dan meningkat sebesar 3,16 pada siklus 2 Penerapan model pembelajaran Snowball Throwing dapat meningkatkan keterampilan siswa kelas IV SD Negeri 165721
Kota Tebing Tinggi pada pelajaran Pendidikan Kewarganegaraan. Peningkatan hasil belajar diperoleh dari hasil tes tindakan setiap siklus, dimana siklus I mencapai $75,00 \%$, dan siklus II mencapai 92,86\%.

2. Penerapan model pembelajaran snowball throwing sudah terlaksana sesuai dengan skenario pembelajaran di kelas IV SD Negeri 165721 Kota Tebing Tinggi. Keterlaksanaan dari siklus 1 mencapai rata-rata sebesar $75,00 \%$, dan siklus 2 mencapai rata-rata sebesar $92,86 \%$.

Setelah melaksanakan penelitian dan melihat hasil yang didapatkan, maka peneliti menyarankan sebagai berikut:

1. Kepada para Guru diharapkan dapat menerapkan pembelajaran kooperatif khususnya model pembelajaran snowball throwing dalam proses pembelajaran Pendidikan Kewarganegaraan

2. Kepada para peneliti selanjutnya diharapkan dapat melakukan penelitian tentang penerapan model pembelajaran yang lain yang dapat membangkitkan keaktifan siswa untuk belajar Pendidikan Kewarganegaraan.

\section{DAFTAR RUJUKAN}

Arikunto. 2003. Teknik Analisis Data. Jakarta: Universitas Terbuka.

Fauzi AN. 2005. Penggunaan Pendekatan Pembelajaran Kooperatif Jigsaw Untuk Meningkatkan Hasil Belajar 
Aridawaty: Peningkatan Hasil Belajar Siswa ...

$\begin{array}{lr}\text { Siswa Pada } & \text { Konsep } \\ \text { Pertumbuhan } & \text { dan } \\ \text { Perkembangan } & \text { Hewan. } \\ \text { Skripsi. Semarang: } & \text { FMIPA } \\ \text { UNNES. } & \end{array}$

Ibrahim M., dkk. 2001. Pembelajaran Kooperatif. Surabaya: UNESA-Universitas Press.

Kaelan \& Zubaidi. 2007. Identitas Negara Republik Indonesia. Jakarta: Cipta Karya.

Mariyana, Rita. 2005. Strategi Pengelolaan Lingkungan Belajar Di Taman Kanak Kanak. Jakarta: Departemen Pendidikan Nasional.

Oemar, Hamalik. 2003. Proses Belajar Mengajar. Jakarta: PT. Bumi Aksara.

Payerli. 2013. Pendidikan Kewarganegaraan. Medan: Unimed Press.

Riduwan. 2004. Belajar Mudah Penelitian Untuk GuruKaryawan dan Peneliti Pemula. Bandung: Alfabeta.

Suyitno, Amin. 2006. Petunjuk Praktis Penelitian Kelas. Semarang: FPMIPA UNNES.

Yahya, dkk. 2010. Persatuan dan Kesatuan Nasional. Bandung: Replika. 